Check for updates

The BMJ

rhurley@bmi.com Follow Richard on Twitter @rich_hurley Cite this as: BMJ 2021;372:n536 http://dx.doi.org/10.1136/bmj.n536 Published: 25 February 2021

\title{
It's self-interest to share our vaccines globally
}

\section{Richard Hurley features and debates editor}

The NHS has administered a covid-19 vaccine to more than 18 million people, a quarter of the UK population, since December-an extraordinary logistical achievement. ${ }^{1}$

But vaccinating everybody here will not protect us from longer term harm, say infectious disease experts, including the government's SAGE adviser and Wellcome Trust director, Jeremy Farrar, in The BMJ Interview this week, ${ }^{2}$ also available in podcast (bmj.com/archive/podcasts).

It's a public health and economic imperative, Farrar says, that once we have vaccinated vulnerable people and healthcare workers in the UK we should make vaccines available to these groups worldwide.

What he terms “enlightened self-interest" echoes recent calls by the World Health Organization and World Trade Organization. ${ }^{34}$ The longer that SARS-CoV-2 is in circulation anywhere, the greater the chance that variants with resistance to existing treatments and vaccines will emerge and spread. ${ }^{5}$

Vaccine nationalism will cost \$3.4 trillion a year, says the US non-profit RAND Corporation, ${ }^{6}$ and global economic crashes reverberate at home. Rich countries could get $€ 4.80$ ( $€_{5.60}$; $\$ 6.80$ ) in return for every $€ 1$ invested in vaccination in poorer ones because of lower losses to global productivity, RAND's modelling finds.

Although many countries have joined Covax, the international partnership tasked with equitable vaccine deployment, to date three quarters of all doses have been administered in just 10 countries. ${ }^{7}$ Two thirds of all countries have received no covid-19 vaccines.

The UK has ordered at least 400 million vaccine doses and promised to share its "surplus" with poorer countries-but without saying how much and how soon. ${ }^{7}$ The UK has also pledged $€ 548 \mathrm{~m}$ to Covax, but money can't help poorer countries if richer ones hoard all the vaccines.

The UK government, facing sustained criticism for policies that led to 130 ooo covid-19 deaths, is keen to keep the spotlight on the success of its domestic vaccination programme, a critical step to its "road map" out of lockdown. ${ }^{8}$

Indeed it has just announced that all adults will be offered a first dose by 31 July, bringing the target forward a month, but this is not necessarily good for global equity or the best strategy to control the pandemic domestically. ${ }^{9}$ Perhaps it was coincidence that this news coincided with the High Court ruling that England's health secretary had acted unlawfully in not publishing the details of contracts worth billions of pounds awarded without competition during the pandemic? ${ }^{10} 11$
Until we're all safe, none of us is safe. Let's show enlightened self-interest and altruism and immediately commit to sharing vaccines equitably around the world.

1 Gov.UK. Coronavirus (covid-19) in the UK. 23 Feb 2021. https://coronavirus.data.gov.uk/details/vaccinations.

2 Looi M-K. Jeremy Farrar: Make vaccine available to other countries as soon as our most vulnerable people have received it. BMJ2021;372:n459. doi: 10.1136/bmj.n459 pmid: 33608412

3 Eaton L. Covid-19: WHO warns against "vaccine nationalism" or face further virus mutations. BMJ2021;372:n292 doi: 10.1136/bmj.n292 pmid: 33526414

4 Limb M. Covid-19: Plans to share vaccines aren't enough, says charity. BMJ 2021;372:n516. doi: 10.1136/bmj.n516 pmid: 33619121

5 McNally A. What makes new variants of SARS-CoV-2 concerning is not where they come from, but the mutations they contain. BMJ2021;372:n504 doi: 10.1136/bmj.n504 pmid: 33619064

6 Hafner M, Yerushalmi E, Fays C, Dufresne E, Van Stolk C. Covid-19 and the cost of vaccine nationalism. Rand Corporation. 2020. https://www.rand.org/pubs/research_reports/RRA769-1.html.

7 Limb M. Covid-19: Plans to share vaccines aren't enough, says charity. BMJ 2021;372:n516. doi: 10.1136/bmi.n516 pmid: 33619121

8 lacobucci G, Mahase E. Covid-19: Vaccine success drives England's lockdown exit. BMJ2021;372:n528doi: 10.1136/bmj.n528.

9 Majeed A. Can the UK meet its target of offering all adults a covid-19 vaccine by 31 July? BMJ Opinion. 22 Feb 2021

https://blogs.bmj.com/bmj/2021/02/22/can-the-uk-meet-the-governmentstarget-of-offering-all-adults-a-covid-19-vaccine-by-31-july.

10 lacobucci G. Covid-19: Government has spent billions on contracts with little transparency, watchdog says. BM/2020;371:m4474 doi: 10.1136/bmj.m4474 pmid: 33208349

11 Dyer C. Covid-19: Hancock's failure to publish contracts was unlawful. BMJ 2021;372:n511. doi: 10.1136/bmj.n511 pmid: 33608255

This article is made freely available for use in accordance with BMJ's website terms and conditions for the duration of the covid-19 pandemic or until otherwise determined by BMJ. You may use, download and print the article for any lawful, non-commercial purpose (including text and data mining) provided that all copyright notices and trade marks are retained. 